\title{
Glucocorticoids and the preparation for life after birth: are there long-term consequences of the life insurance?
}

\author{
Abigail L. Fowden*, Juan Li and Alison J. Forhead \\ Department of Physiology, University of Cambridge, Downing Street, Cambridge CB2 3EG, UK
}

In mammals, survival both before and after birth depends on a number of key physiological processes such as the provision of $\mathrm{O}_{2}$, a supply of oxidative substrates and a means of removing the waste products of metabolism. In adults these processes are carried out by a number of different tissues, whereas in the fetus they are carried out primarily by the placenta. The successful transition from intra- to extra-uterine life, therefore, depends on the ability of specific tissues and organ systems to take over the functions of the placenta at birth. Consequently, organs such as the lungs, liver, kidneys and gut undergo maturational changes during late gestation in preparation for extra-uterine life. Most of these changes are glucocorticoid dependent and can be induced prematurely by exogenous glucocorticoid administration (Silver, 1990; Liggins, 1994; Fowden, 1995). As a consequence, synthetic glucocorticoids are now routinely administered to women in threatened preterm labour to improve neonatal viability (NIH Consensus Development Conference, 1995).

In all species studied so far, there is an increase in the circulating glucocorticoid concentration in the fetus towards term (Fig. 1). The magnitude and timing of this cortisol surge vary between species, as does the precise mechanism by which it occurs (Fig. 1; Fowden \& Silver, 1995; Wood \& Cudd, 1997). In most species, the prepartum cortisol surge is due to increased adrenal cortisol output, but in certain animals, such as the rat and horse, its effect is enhanced by a fall in the level of plasma corticosteroidbinding globulin (Challis et al. 1993; Wood \& Cudd, 1997). In normal conditions, therefore, fetal tissues are exposed to increasing levels of bioactive glucocorticoid for periods of up to $10-15 \mathrm{~d}$ before delivery.

\section{Maturational effects of the glucocorticoids}

Glucocorticoids have been shown to have a wide range of maturational effects in utero (Table 1). They induce both structural and functional changes in a variety of different fetal tissues and activate many of the biochemical processes which have little or no function in fetal life (Table 1). They affect not only those tissues essential for survival immediately at birth, but also organs involved in the more long-term adaptation to extra-uterine life (Liggins, 1994).

\section{Specific tissues}

Lung. The lung is the tissue on which immediate neonatal survival most depends and its maturation is highly glucocorticoid dependent (Kitterman et al. 1981). Structurally, cortisol increases lung compliance by accelerating alveolarization, thinning the septae and by increasing the pulmonary content of collagen and elastin (Crone et al. 1983; Schellenberg et al. 1987; Warburton et al. 1988). In fetal rats, glucocorticoids increase both the number of cells in the lung expressing the tropoelastin gene and the amount of expression per cell (Pierce et al. 1995). Glucocorticoids also act functionally to prepare the fetal lung for gas exchange. They increase synthesis of both the lipid and

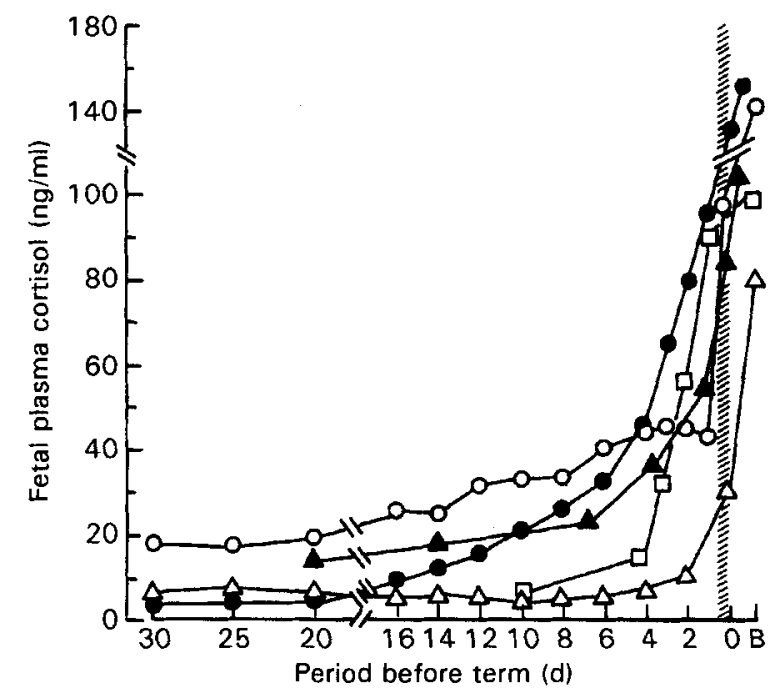

Fig. 1. Mean fetal concentrations of plasma cortisol with respect to time period (d) from delivery in the sheep (O), pig (O), man ( $\Delta$ ), guinea-pig $(\square)$, and horse $(\triangle)$. ( Labour; $B$, birth. (Data from Silver \& Fowden, 1988.)

\footnotetext{
Abbreviations: GH, growth hormone; GRE, glucocorticoid response elements; HPA, hypothalamic-pituitary-adrenal; IGF, insulin-like growth factor; $11 \beta \mathrm{HSD}, 11 \beta$-hydroxysteroid dehydrogenase.

*Corresponding author: Dr A. L. Fowden, fax + 44 (0)1223 333 840, email alf1000@cus.cam.ac.uk
} 
Table 1. Some of the maturational changes induced by cortisol in fetal ovine tissues essential for neonatal survival (Data from Silver, 1990; Liggins, 1994; Fowden, 1995; Segar et al. 1995; Li et al. 1996b; Phillips ID et al. 1997).

\begin{tabular}{ll}
\hline Tissue & \multicolumn{1}{c}{ Maturational change } \\
\hline Lung & Surfactant production and release \\
& Collagen and elastin synthesis \\
$\beta$-Adrenoreceptor induction \\
Lung liquid re-absorption \\
Structural maturation of alveoli \\
\\
Glycogen deposition \\
Gluconeogenic enzyme induction \\
IGF-gene expression \\
$\beta$-Adrenoreceptor induction \\
Prolactin-receptor induction \\
GH-receptor induction \\
CBG synthesis \\
Angiotensinogen-gene down-regulation
\end{tabular}

Kidney Increased glomerular filtration rate Tubular Na re-absorption lon-exchange-pump induction Erythropoietin-gene down-regulation $\mathrm{AT}_{1}$-receptor-gene down-regulation Renin-gene down-regulation

$\begin{array}{ll}\text { Gut } & \text { Mucosal growth } \\ & \text { Acid secretion } \\ & \text { Digestive-enzyme induction } \\ & \text { Gastrin secretion }\end{array}$

Adrenal Cytoarchitecture of zona fasciculata Induction of P450 cytochromes Induction of PNMT enzyme Induction of ACTH receptors

IGF, insulin-like growth factor; $\mathrm{GH}$, growth hormone; CBG, corticosteroidbinding globulin; $A T_{1}$, angiotensin 1 ; renin, $E C$ 2.4.23.15; PNMT, phenylethanolamine $\mathrm{N}$-methyltransferase (EC 2.1.1.28); $\mathrm{ACTH}$, adrenocorticotrophic hormone.

protein components of surfactant and enhance its release from the type II pneumocytes into the alveoli (Kitterman $e t$ al. 1981). Surfactant synthesis is enhanced partially by induction of the rate-limiting enzymes involved in phosphatidylcholine synthesis, and partially by activation of glycogenolysis which provides substrate for phospholipid synthesis (see Liggins, 1994). In addition, glucocorticoid enhances the liquid resorptive capacity of the fetal lung (Wallace et al. 1995) by inducing ion channels in the pulmonary epithelium and by increasing the density of the alveolar $\beta$-adrenoreceptors which activate these channels (Warburton et al. 1988; Ingbar et al. 1997).

Liver. In the liver, the maturational effects of cortisol appear to be primarily functional (Silver, 1990). Cortisol increases the synthesis of a wide range of proteins in the fetal liver including receptors, enzymes, binding proteins and growth factors (Table 1). It also increases the deposition of hepatic glycogen by enhancing the activity of glycogen synthetase (EC 2.4.1.21; Jones \& Rolph, 1985). In all species studied so far, there is an increase in hepatic glycogen deposition towards term which closely parallels the normal prepartum rise in fetal plasma glucocorticoids (Shelley, 1961; Fowden et al. 1991). When this glucocorticoid surge is prevented by fetal adrenalectomy or hypophysectomy, glycogen levels in the fetal liver remain low (Fig. 2). Conversely, raising plasma cortisol at
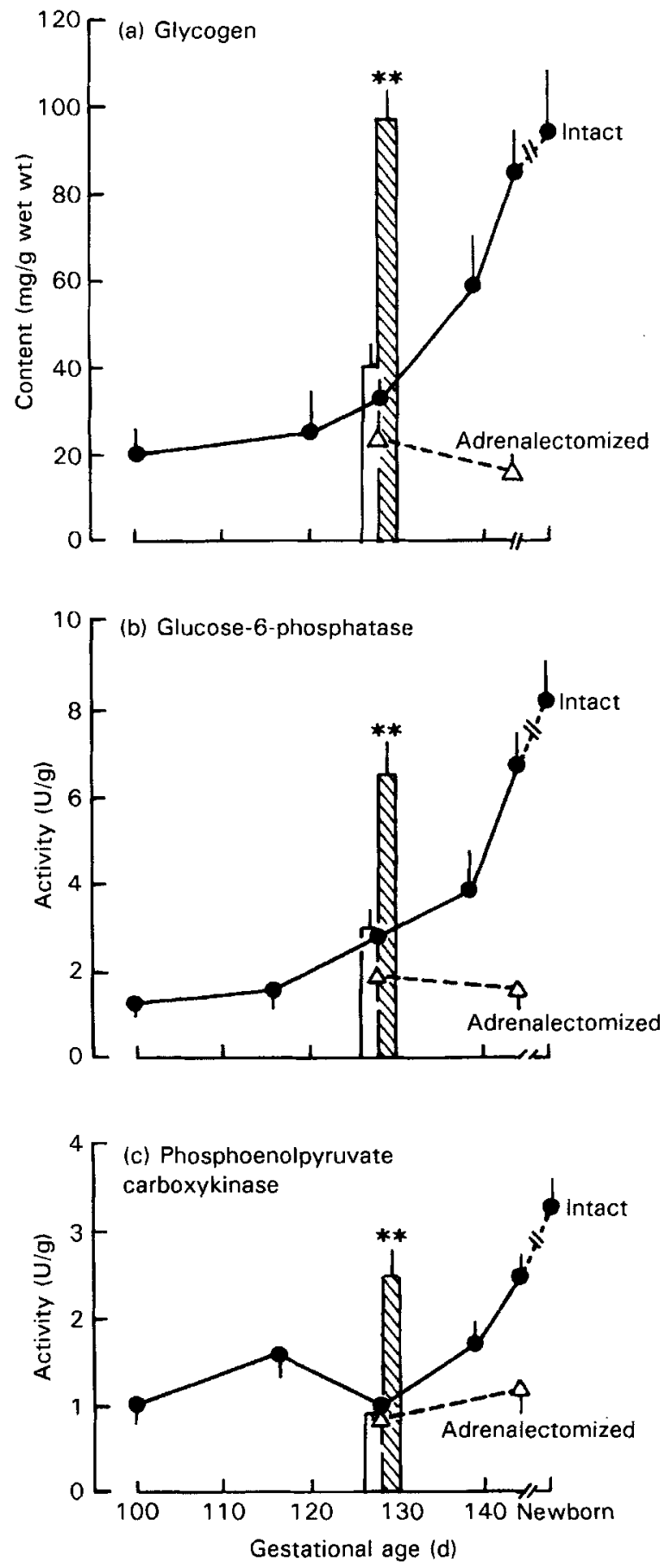

Fig. 2. Values for hepatic glycogen (a), glucose-6-phosphatase $(E C$ 3.1.3.9; b) and phosphoenolpyruvate carboxykinase (EC 4.1.1.38; c) in liver from intact $(\Theta)$ and adrenalectomized $(\Delta)$ sheep fetuses with respect to gestational age and in intact fetuses infused with cortisol (2-3 mg/kg per d; or saline $(9 \mathrm{~g} \mathrm{NaCl} / \mathrm{l} ; \square)$ for $5 \mathrm{~d}$ before delivery. Values are means with their standard errors represented by vertical bars. Mean values were significantly different from those for salineinfused fetuses: ${ }^{\star *} P<0.01$. (Data from Barnes et al. 1978; Fowden et al. 1993.)

a time when concentrations are normally low leads to a premature increase in glycogen deposition in a number of species, including the rat, sheep, pig and monkey (Fig. 2; Jones \& Rolph, 1985; Klepac, 1985; Fowden et al. 1995). 
Glucocorticoids also induce the activity of several other rate-limiting enzymes in the fetal liver (Liggins, 1994). In particular, they increase the levels of fatty acid synthase (EC 2.3.1.85), aminotransferases and all the key gluconeogenic enzymes (Fig. 2; Jones \& Rolph, 1985; Fowden et al. 1993). Cortisol has also been shown to be responsible for the normal prepartum rise in corticosteroid-binding globulin synthesis in the liver and in the hepatic activity of the $5^{\prime}$ monodeiodinase which stimulates outer-ring deiodination of thyroxine to triiodothyronine (thyroxine deiodinase; $E C$ 3.8.1.4; Wu et al. 1978; Jeffray et al. 1995). The ontogenic up-regulation in receptor density for growth hormone $(\mathrm{GH})$, prolactin and $\beta$-adrenoreceptors in the ovine fetal liver is also dependent on the fetal plasma cortisol surge (Li et al. 1996b; Barnes, 1997; Phillips ID et al. 1997).

Glucocorticoids do not only up-regulate protein synthesis in the liver. They also suppress gene expression for a number of specific proteins including angiotensinogen, insulin-like growth factor (IGF)-II and certain of the IGFbinding proteins (Olson et al. 1991; Price et al. 1992; Li et al. 1993). The maturational effects of cortisol on the fetal liver, therefore, affect the functioning of several fetal endocrine systems (e.g. the renin-angiotensin II, somatotrophic, thyroid and pituitary-adrenal axes) which will have widespread effects elsewhere in the body.

Gut. Glucocorticoids have both structural and functional effects on the gut (Table 1). In the fetal pig and sheep, they affect villus-crypt architecture in the stomach and small intestine and induce digestive enzymes in all parts of the gastrointestinal tract (Table 1). In fetal sheep, cortisol increases villus height and density and thins the musculari externa in the small intestine (Trahair et al. 1987b). It also increases the rate of migration of enterocytes up the villi (Trahair et al. 1987b). These changes mimic those seen close to term, which suggests that the prepartum cortisol surge is responsible for the normal sequence of development observed in the fetal gut towards term (Trahair \& Sangild, 1997). Certainly, these changes in gut morphology are abolished by adrenalectomizing the fetus (Trahair $e t$ al. 1987a). Similarly, fetal adrenalectomy prevents the normal prepartum increases in the activity of abomasal pepsinogen and prochymosin and of pancreatic amylase (EC 3.2.1.1) and chymotrypsin ( $E C$ 3.4.21.1) in the sheep fetus (Sangild et al. 1995b). In the pig, intra-fetal cortisol administration during late gestation has been shown to stimulate digestive activity in the stomach, pancreas and small intestine (Sangild et al. 1994a,b,c, 1995a). In the stomach, cortisol increases gastrin release, acid secretion and the number and distribution of the prochymosin-containing cells in the fundic glands (Sangild et al. 1994a,b). In the pancreas, there are increases in the amylase and trypsin ( $E C$ 3.4.21.4) content in response to elevating cortisol levels for $6 \mathrm{~d}$ before delivery (Sangild et al. 1994c). In the small intestine, activities of all the major brush-border hydrolases are increased in cortisol-treated fetal pigs (Fig. 3; Sangild et al. $1995 a$ ). In both the fetal sheep and pig, the maturational effects of cortisol on the gut proceed in a proximal to distal direction, with the most pronounced effects in the stomach and proximal small intestine (Trahair \& Sangild, 1997).

Kidney. In comparison with other fetal tissues, relatively little is known about the maturational effects of glucocorticoids on renal development (Lumbers, 1995). In late gestation, glucocorticoids appear to have functional rather than structural effects on the fetal kidneys, although earlier in gestation they may affect nephrogenesis (Wintour \& Moritz, 1997). Near term, glucocorticoid administration has been shown to increase tubular re-absorptive capacity and reduce the fractional $\mathrm{Na}$ excretion in fetal rats and lambs (Stonestreet et al. 1983; Slotkin et al. 1992). In the lamb, these changes are accompanied by increases in the glomerular filtration rate and total renal blood flow (Stonestreet et al. 1983). The cortisol-induced fall in fractional $\mathrm{Na}$ excretion is due primarily to an increase in distal tubular $\mathrm{Na}$ re-absorption and is associated with a rise in $\mathrm{Na}^{+} / \mathrm{K}^{+}$-ATPase (EC 3.6.1.37) mRNA abundance in the fetal ovine kidney (Towstoless et al. 1989; Celsi et al. 1993). Increases in $\mathrm{Na}^{+}-\mathrm{H}^{+}$exchanger activity and in the mRNA abundance for this transporter have also been observed in proximal tubules from cortisol-treated fetal sheep (Guillery et al. 1995).

Maturation of the endocrine functions of the kidney also appears to be influenced by glucocorticoids. Renal erythropoietin-gene expression normally declines towards term and can be down-regulated prematurely by preterm cortisol infusion ( $\mathrm{Lim}$ et al. 1996). Conversely, the normal prepartum suppression of this gene is prevented by fetal adrenalectomy (Lim et al. 1996). Preterm cortisol infusion into fetal sheep also reduces renal angiotensin II type 1receptor mRNA abundance and lowers basal plasma renin (EC 2.4.23.15) and renal renin mRNA levels (Wood et al. 1987; Carbone et al. 1995; Segar et al. 1995). However, renin responses to specific and haemorrhage-induced hypotension are enhanced in sheep fetuses pretreated with cortisol (Wood et al. 1984; Carbone et al. 1995). Glucocorticoids, therefore, appear to adapt the kidney from a saltlosing to a salt-conserving organ during the perinatal period.

\section{Physiological systems}

Many of the processes essential for postnatal survival in the long term, such as thermoregulation, fluid and metabolic balance, require the coordinated development of several different tissues and organ systems. For instance, maintaining a supply of oxidative substrates during the transition from parenteral to enteral nutrition involves the liver, gut, muscle and various other tissues (see Silver, 1990). During the period between placental separation and the establishment of nutritive suckling, the endogenous fuel reserves provide the nutrients, but once lactation and suckling begin, the gut takes over as the principal source of oxidizable substrates. The mechanisms regulating substrate utilization and the circulating metabolite concentrations must also adapt at birth from the continuous but finite supply of nutrients in utero to the more plentiful yet intermittent pattern of postnatal nutrition. Coordination of these and many of the other complex perinatal adaptations depends heavily on the glucocorticoids.

Cortisol acts through a number of different mechanisms to ensure a supply of nutrients immediately after birth (Fowden, 1995). It increases the storage of glucose as 
(a) Stomach: prochymosin

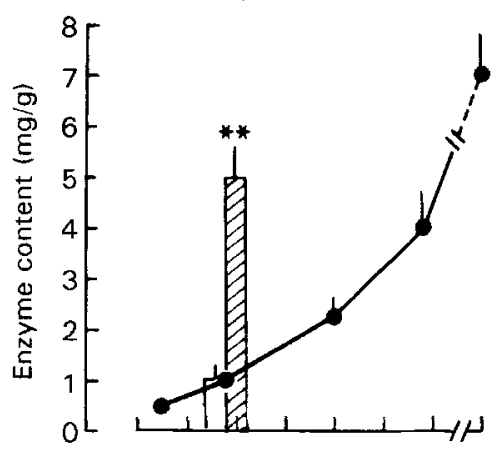

(c) Small intestine: lactase

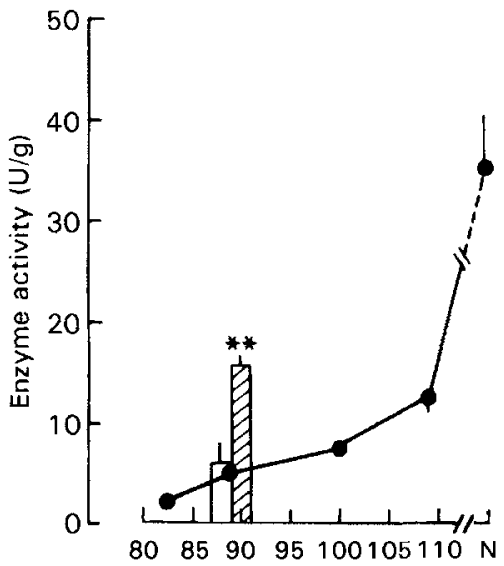

(b) Pancreas: amylase

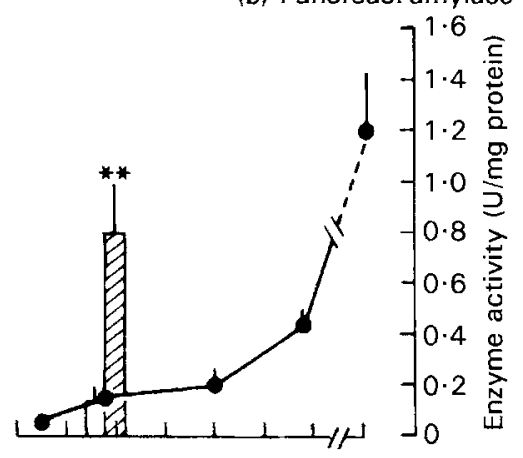

(d) Small intestine: aminopeptidase

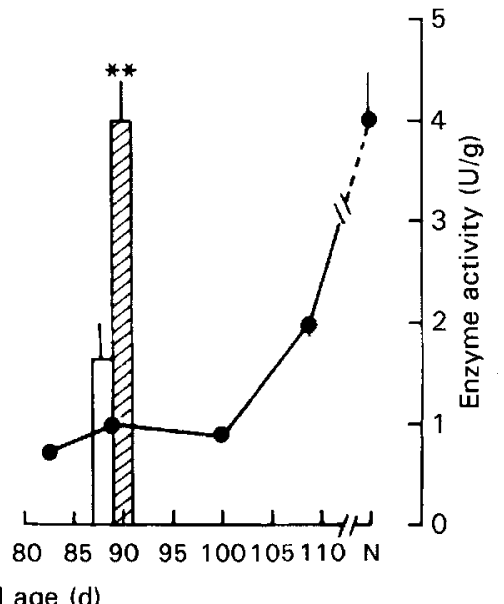

Fig. 3. Values for (a) stomach prochymosin, (b) pancreatic amylase (EC 3.2.1.1), (c) lactase (EC 3.2.1.108) and (d) aminopeptidase (EC 3.4.11.11) in the small intestine of the fetal pig with respect to gestational age ( $; n>4$ in each group) and in fetuses infused with cortisol $(1-3 \mathrm{mg} / \mathrm{kg}$ per d; $\mathbb{2})$ or saline $(9 \mathrm{~g} \mathrm{NaCl} / \mathrm{l} ; \square)$ for $6 \mathrm{~d}$ before delivery. $\mathrm{N}$, newborn. Values are means with their standard errors represented by vertical bars. Mean values were significantly different from those for saline-infused fetuses: ${ }^{* *} P<0.01$. (Data from Sangild et al. 1994b,c, 1995a.)

glycogen in a variety of tissues and induces the enzymes responsible for producing circulating glucose from both glycogen and other precursors such as lactate and amino acids in the fetal liver and kidney (Fowden et al. 1993, 1995). Cortisol, therefore, helps maintain the circulating glucose level by enhancing the glucogenic capacity of the liver and kidneys and by providing specific glucose reserves in tissues, such as cardiac and skeletal muscle, which can meet their glucose requirement in the short term without drawing on the circulating glucose pool (Fowden et al. 1991, 1993). In addition, by stimulating hepatic $\beta$ adrenergic receptors, cortisol may enhance the capacity for sympatho-adrenal activation of hepatic glucose production (Fowden et al. 1995). Indeed, cortisol has been shown to stimulate hepatic glucose production in sheep fetuses close to term (Townsend et al. 1991; Barbera et al. 1997). Furthermore, the maturational effects of cortisol on the adrenal medulla increase the availability of adrenaline which, in turn, can activate the glucogenic and lipolytic pathways (Table 1; Barnes, 1977). The prepartum cortisol surge, therefore, has a key role both in ensuring that there are adequate fuel reserves at birth and in initiating their mobilization once delivery has occurred.
Glucocorticoids are also involved in the adaptations to enteral feeding. In stimulating structural and functional changes in the proximal regions of the gut, cortisol ensures that nutrients delivered to the gut can be digested and absorbed efficiently shortly after birth (Trahair \& Sangild, 1997). Growth factors present in the milk can then complete the process of gastrointestinal maturation, particularly in the distal regions, via both luminal and systemic mechanisms (Trahair \& Sangild, 1997). The effects of cortisol on the secretion of gastrin and other gut peptides indicate that it may also have an important role in the onset of the local and endocrine control mechanisms characteristic of postnatal gastrointestinal function (Trahair, 1993). Certainly, gastrointestinal function is poor in animals delivered prematurely before the final cortisol surge (Moog, 1979).

Less is known about the effects of glucocorticoids on the mechanism regulating the utilization and circulating concentrations of nutrients. Cortisol is known to depress umbilical glucose uptake and alter amino acid uptake and utilization by the sheep fetus in utero (Milley, 1996; Barbera et al. 1997), but the effects of prenatal glucocorticoid exposure on substrate utilization after birth remain 
unknown. Recent studies have suggested that the prenatal cortisol surge initiates a switch in the nutritional regulation of growth by activating the $\mathrm{GH}$ dependence of the somatotrophic axis ( $\mathrm{Li}$ et al. 1996b). Cortisol infusion into the sheep fetus before term induced hepatic GH-receptorgene expression while, conversely, abolition of the cortisol surge by fetal adrenalectomy prevented the normal upregulation of this gene towards term (Li et al. 1996b).

Excessive glucocorticoid in utero has also been shown to alter the subsequent sensitivity of the hypothalamicpituitary-adrenal (HPA) axis to physiological challenges such as fasting (Seckl, 1997a). This effect is mediated, at least in part, via alterations in glucocorticoid-receptor-gene expression in brain regions involved in the feedback control of the HPA axis (Levitt et al. 1996). Since glucocorticoidreceptor-gene expression is known to change in these regions of the fetal brain towards term (Matthews et al. 1995), it is possible that the endogenous rise in cortisol before birth resets the HPA axis for the new nutritional and other environmental conditions that prevail after birth.

\section{Mechanisms of glucocorticoid action}

Glucocorticoids stimulate tissue maturation via several different direct and indirect mechanisms which alter the balance between tissue accretion and differentiation. They have been shown to inhibit fetal growth in the rat, sheep, monkey and man (see Seckl, 1994; Fowden, 1995). In the sheep fetus, growth rate, measured as crown-rump increment, decreases by $50 \%$ over the period of late gestation during which fetal cortisol levels rise (Fowden $e t$ al. 1996). This prepartum decline in growth rate is prevented by fetal adrenalectomy and can be stimulated prematurely by raising cortisol levels to prepartum values by exogenous cortisol infusion (Fowden et al. 1996). Adrenalectomized sheep fetuses are also heavier at term and have changes in protein:DNA in certain individual tissues that are indicative of maintained cell division (Barnes et al. 1978; Fowden et al. 1996; Wallace et al. 1996). Glucocorticoids, therefore, appear to trigger maturation by switching the cell cycle from proliferation to differentiation.

This action of the glucocorticoids is mediated, at least in part, by alterations in gene expression and tissue content of the IGF. These IGF genes are known to be developmentally regulated and have been shown to be essential for normal intra-uterine growth (see Gluckman, 1995). Expression of the IGF-II gene, in particular, is high in utero compared with postnatal values (Delhanty \& Han, 1993). In late gestation, expression of both IGF genes is directly related to the circulating cortisol concentration in utero ( $\mathrm{Li}$ et al. 1993, 1996b). In fetal sheep, cortisol suppresses IGF-II mRNA abundance in the fetal liver, muscle and adrenal, and is responsible for the developmental down-regulation of this gene towards term (Fig. 4; Li et al. 1993, 1996b; Lü et al. 1994). It also reduces IGF-I-gene expression in ovine skeletal muscle independently of any change in $\mathrm{GH}$ receptor-gene expression (Fig. 4). This cortisol-induced suppression of IGF-gene expression will reduce the drive for fetal growth and may act as a specific signal for cell differentiation. Certainly, in fetal sheep, the prepartum changes in muscle IGF-gene expression are coincident with the final stages of secondary myofibre differentiation (see Dauncey \& Gilmour, 1996).

In contrast to muscle, cortisol up-regulates total IGF-I mRNA abundance in fetal ovine liver (Li et al. 1996a, 1997). This effect appears to be mediated by the increment in hepatic GH-receptor abundance and is accompanied by a preferential increase in the GH-sensitive transcript of the IGF-I gene (Li et al. 1996b). By inducing the switch from IGF-II to GH-dependent IGF-I-gene expression in the liver, cortisol initiates the transition from local to endocrine IGF production and, thereby, ensures that rapid tissue accretion can resume after birth despite the changed pattern of nutrition.

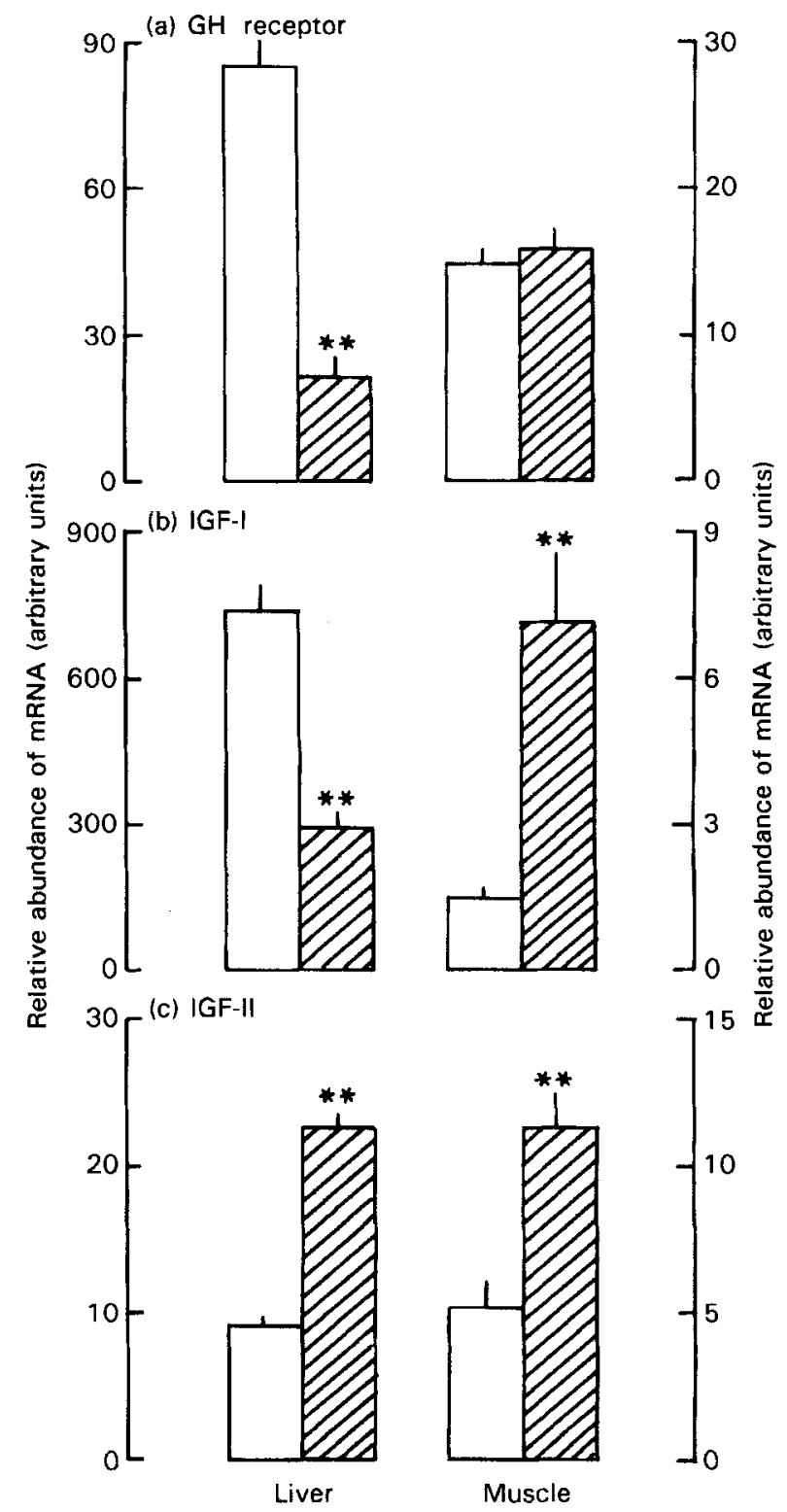

Fig. 4. Relative abundances of (a) growth hormone (GH)-receptor mRNA, (b) total insulin-like growth factor (IGF)-I mRNA and (c) IGF-II mRNA in liver and skeletal muscle from intact $(\square)$ and adrenalectomized (包) sheep fetuses at 142-145 d of gestation (term 145 $\pm 2 \mathrm{~d}$ ). Mean value significantly different from that observed in the intact animals: ${ }^{\star \star} P<0.01$. (Data from $\mathrm{Li}$ et al. 1993, 1996b, 1997.) 
At a molecular level, glucocorticoids affect a number of different processes. They can act on transcription, mRNA stability, translation and/or on the post-translational processing of the protein products (Burnstein \& Cidlowski, 1989; Venkatesh \& Ballard, 1991). Several of the genes known to be regulated by glucocorticoids in utero (e.g. IGF-II, angiotensinogen, tropoelastin, erythropoietin) have the necessary glucocorticoid response elements (GRE) in their promotor regions to allow direct transcriptional control of the gene by cortisol (Olson et al. 1991; Li, 1994; Pierce et al. 1995; Lim et al. 1996). However, other genes which are apparently glucocorticoid sensitive (e.g. IGF-I) do not appear to have recognizable GRE consensus sequences (Dickson et al. 1991). In these instances, the effects of cortisol must be mediated indirectly either by post-transcriptional control of steady-state levels of mRNA or through other transcription factors with full-length or half-site GRE sequences (Venkatesh \& Ballard, 1991; Lim et al. 1996). Alternatively, cortisol may act through triiodothyronine. Genes without GRE sequences often have triiodothyronine consensus sequences and plasma triiodothyronine is known to rise concomitantly with plasma cortisol as a result of the cortisol-induced deiodination of thyroxine to triiodothyronine (Wu et al. 1978; Venkatesh \& Ballard, 1991). Indeed, synergism between plasma triiodothyronine and cortisol has been observed in a number of prepartum maturational processes including lung liquid reabsorption and down-regulation of hepatic IGF-II-gene expression (Barker et al. 1991; Forhead et al. 1996). In genes which have multiple transcripts derived from alternate exon slicing and promotor usage, the effects of glucocorticoids may be specific to certain leader exons in the $5^{\prime}$ untranslated region. In the IGF-II gene, cortisol down-regulates exon 7-containing but not exon 6-containing transcripts ( $\mathrm{Li}, 1994)$. Similarly, cortisol preferentially increases the class 2 transcript of the IGF-I gene and switches on the adult, liver-specific leader exon of the GH receptor (exon 1a) in the liver of fetal sheep close to term (Li et al. 1996a,b). Thus, part of the maturational effect of the glucocorticoids may be to initiate use of specific promotors which, in turn, alters the nature of the gene product and its potential for translation (Roberts, 1997).

Some of the maturational effects of cortisol appear to be specific to particular periods of development. For instance, cortisol down-regulates hepatic IGF-II-gene expression in fetal sheep at $130 \mathrm{~d}$ of gestation but not in younger animals (Li et al. 1993; Li, 1994). Similarly, cortisol leads to tubular $\mathrm{Na}$ re-absorption in fetal sheep close to term, but causes naturiesis in fetuses at $110 \mathrm{~d}$ of gestation (Towstoless et al. 1989). The ability of exogenous cortisol to induce digestive enzymes in the small intestine of the fetal pig also appears to be confined to the period of late gestation just before the endogenous cortisol level normally rises (Trahair \& Sangild, 1997). These time-dependent effects of the glucocorticoids may be due partially to ontogenic changes in glucocorticoid-receptor density and partially to alterations in the isoform and activity of $11 \beta$-hydroxysteroid dehydrogenase ( $E C$ 1.1.1.146; $11 \beta$ HSD). This enzyme is present in many fetal tissues and converts cortisol to its inactive metabolite, cortisone, and vice versa depending on the specific isoform present in the tissue (Yang, 1992). It therefore regulates the bioavailability of cortisol to the fetal tissues (Chapman et al. 1997). In turn, both $11 \beta$ HSD and glucocorticoid-receptor-gene expression can be regulated by cortisol (Yang, 1992; Matthews et al. 1995). The precise maturation effects induced by cortisol, therefore, depend on the duration, magnitude and developmental timing of the increment in plasma cortisol.

\section{The long-term consequences of intra-uterine glucocorticoid exposure}

In normal conditions, glucocorticoid concentrations only rise just before term as a signal for tissue maturation (see Silver, 1990). In these circumstances, prenatal glucocorticoid exposure appears to have few adverse sequalae, as the fetal tissues have proliferated normally up to a point at which the prepartum cortisol surge triggers differentiation. However, in stressful intra-uterine conditions such as placental insufficiency, undernutrition or restricted blood flow (Fig. 5), the fetal HPA axis is activated earlier in development and fetal cortisol levels become elevated well before term (Challis et al. 1993; Wood \& Cudd, 1997). Although glucocorticoid exposure in these circumstances will ensure survival should delivery occur, the early switch from cell proliferation to differentiation may lead to an inappropriate pattern of growth for the stage of development, with adverse consequences much later in life (see Barker, 1997). Similarly, in human infants treated antenatally with dexamethasone for threatened preterm delivery or congenital adrenal hypoplasia, over-exposure to glucocorticoids at a time in development when cortisol levels are normally low may have important implications for the subsequent development and long-term health of the child (Seckl, 1997b).

In experimental animals, preterm dexamethasone treatment reduces fetal body weight at delivery and produces persistently elevated blood pressure in the adult offspring (Benediktsson et al. 1993; Dodic et al. 1997). In rats, this treatment also impairs adult glucose tolerance (Lindsay et al. 1996a). Increasing fetal glucocorticoid exposure by inhibiting placental $11 \beta$ HSD has also been shown to lead to hypertension and glucose intolerance in the adult rat (Lindsay et al. 1996b). Although it is not known whether prenatal over-exposure to glucocorticoids in the human infant has similar long-term effects, it does retard intrauterine growth (Reinisch et al. 1978; Buescher et al. 1992). Epidemiological studies in man have recently shown that impaired growth in utero is associated with a substantially increased risk of hypertension, insulin resistance, noninsulin-dependent diabetes mellitus and IHD in adult life (see Barker, 1997). Since fetal cortisol levels are elevated in growth-retarded human infants (Goland et al. 1993), glucocorticoids are also likely to have an important role in the early-life programming of adult cardiovascular and metabolic disease in man.

Glucocorticoids are well placed to have a pivotal role in the prenatal programming of adult disease. Their concentration in utero is increased in response to all the environmental and experimental conditions known to have programming effects in early life (Fig. 5). Prenatally, they 


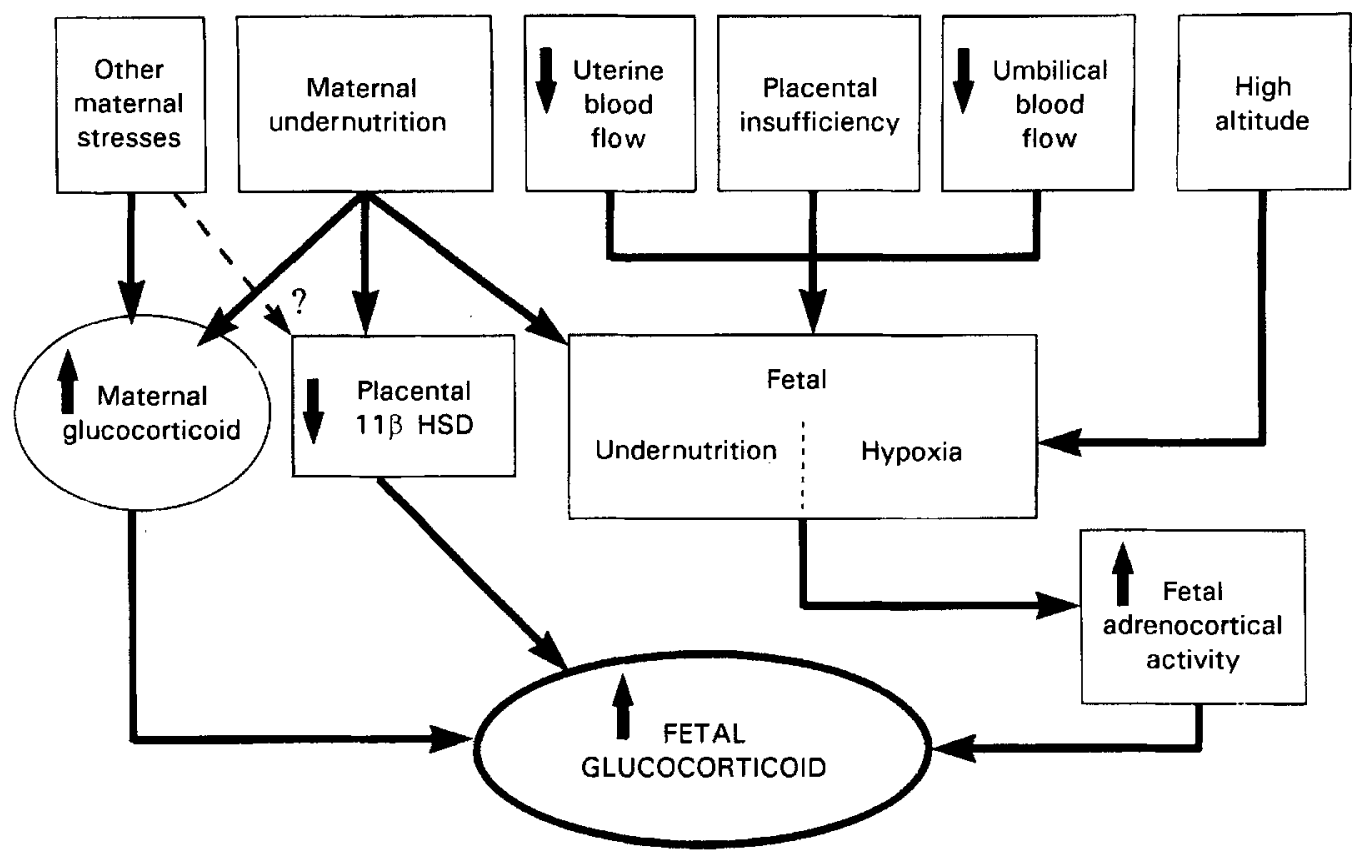

Fig. 5. Schematic diagram to show how fetal cortisol levels are raised by various environmental and experimental conditions believed to exert programming effects during intrauterine development. 11 $\beta$ HSD, 11 $\beta$-hydroxysteroid dehydrogenase (EC 1.1.1.146). (Data from Silver 1990; Challis et al. 1993; Fowden et al. 1995; Barker, 1997; Seckl, 1997a.)

also affect development of the tissues that subsequently show pathophysiology in adult life (see Liggins, 1994). In addition, the observation that the duration, severity and timing of the exposure to glucocorticoids are critical in determining the precise developmental responses are consistent with the epidemiological findings that specific types of intra-uterine growth retardation are related to particular diseases in later life (Barker, 1997).

Inappropriate exposure to glucocorticoids in early life could affect the subsequent functioning of the cardiovascular system in several different ways. First, glucocorticoids may affect the development of the blood vasculature itself. Fetal glucocorticoid administration is known to raise fetal blood pressure, femoral resistance and vascular sensitivity to angiotensin II (Tangalakis et al. 1992; Derks et al. 1997). It also induces permanent changes in adrenergic-receptor expression, and in the intracellular coupling of these receptors which might alter subsequent vascular sensitivity to vasoconstrictors (Seckl, 1997a). There may also be morphological changes in the fetal heart and blood vasculature in response to glucocorticoid administration which contribute to the fetal hypertension and increase the risk of adult cardiovascular disease (Barker, 1997). Second, glucocorticoids may alter the sensitivity of the hypothalamus and HPA axis to feedback from hormones and peripheral chemo- and baroreceptors involved in cardiovascular control (Levitt et al. 1996; Phillips DIW et al. 1997). Third, glucocorticoids may alter cardiovascular function via their effects on renal morphogenesis and the renin-AII system (see p. 115). Glucocorticoids, therefore, have the potential to permanently alter the neural, endocrine and morphological contributions to blood-pressure control in the adult.
Similarly, there are several mechanisms by which overexposure to glucocorticoid in utero may lead to adult glucose intolerance and insulin resistance. Glucose production may be permanently enhanced by the cortisol-induced up-regulation of gluconeogenic activities in the liver and kidney (Fowden et al. 1993; Desai \& Hales, 1997). Alternatively, there may be changes in pancreatic $\beta$ cell function in response to glucocorticoid exposure, although there is little direct evidence, at present, for changes in insulin secretion following manipulation of fetal plasma cortisol (see Fowden, 1985). Finally, glucocorticoids may alter expression of the glucoregulatory genes in tissues, such as skeletal muscle, which make a major contribution to insulin-sensitive glucose disposal. Changes in the availability of glucose transporters and hormone receptors induced in utero may influence the efficiency with which insulin acts in later life and lead to insulin resistance and type 2 diabetes in the long term.

\section{Conclusions}

Glucocorticoids are essential at term for the normal process of prepartum tissue maturation. They stimulate tissue differentiation and coordinate the various adaptations needed to survive the transition from intra- to extra-uterine life. Raising glucocorticoid levels in experimental animals earlier in gestation accelerates this maturational sequence and has led to the routine use of synthetic glucocorticoids in the treatment of preterm delivery in man. While neonatal mortality and morbidity are improved in these circumstances, the stimulation of tissue differentiation at the expense of proliferation may permanently alter cell number 
and function with adverse consequence much later in life. Clearly in treating premature human infants, the potential long-term costs of the life insurance provided by glucocorticoids should be considered carefully.

\section{Acknowledgements}

We would like to thank the many members of the Department, past and present, who helped with these studies and in the preparation of this manuscript. We are also indebted to the Biotechnology and Biological Research Council, The Horserace Betting Levy Board and the Wellcome Trust for their financial support.

\section{References}

Barbera A, Wilkening RB, Teng C, Battaglia FC \& Meschia G (1997) Metabolic alterations in the fetal hepatic and umbilical circulations during glucocorticoid-induced parturition in sheep. Pediatric Research 41, 242-248.

Barker DJP (1997) Fetal nutrition and cardiovascular disease in later life. British Medical Bulletin 53, 96-108.

Barker PM, Walters DV, Markiewicz M \& Strang LB (1991) Development of the lung liquid reabsorptive mechanism in fetal sheep: synergism of triiodothyronine and hydrocortisone. Journal of Physiology 433, 435-449.

Barnes RJ (1997) Perinatal carbohydrate metabolism and the blood flow of the fetal liver. Equine Veterinary Joumal 24, Suppl., 26-31.

Barnes RJ, Comline RS \& Silver M (1978) Effect of cortisol on liver glycogen concentrations in hypophysectomized, adrenalectomized and normal foetal lambs during late or prolonged gestation. Journal of Physiology 275, 567-579.

Benediktsson R, Lindsay R, Noble J, Seckl JR \& Edwards CRW (1993) Glucocorticoid exposure in utero: a new model for adult hypertension. Lancet 341, 339-341.

Buescher MA, McClamrock HD \& Adashi EY (1992) Cushing syndrome in pregnancy. Obstetrics and Gynecology 79, 130137.

Burnstein KL \& Cidlowski JA (1989) Regulation of gene expression by glucocorticoids. Annual Review of Physiology 51, 683-699.

Carbone GMR, Sheikh AU, Zehuder T \& Rose JC (1995) Effect of chronic infusion of cortisol on renin gene expression and renin response to hemorrhage in fetal lambs. Pediatric Research 37, 316-320.

Celsi G, Wang ZM, Akusjarvi G \& Aperia A (1993) Sensitive periods for glucocorticoid regulation of $\mathrm{Na}^{+}, \mathrm{K}^{+}$-ATPase mRNA in developing lung and kidney. Pediatric Research 33, 5-9.

Challis JRG, Bassett N, Berdusco ETM, Han VKM, Lï F, Riley SC \& Yang K (1993) Foetal endocrine maturation. Equine Veterinary Journal 14, Suppl., 35-40.

Chapman KE, Kotelevtsev YV, Jamieson PM, Williams JS, Multins JJ \& Seckl JR (1997) Tissue specific modulation of glucocorticoid action by $11 \beta$-hydroxysteroid dehydrogenase. Biochemical Society Transactions 25, 583-587.

Crone RK, Davies P, Liggins GC \& Reid L (1983) The effect of hypophysectomy, thyroidectomy and postoperative infusion of cortisol or adrenocorticotrophin on the structure of the ovine fetal lung. Journal of Developmental Physiology 5, 281-288.

Dauncey MJ \& Gilmour RS (1996) Regulatory factors in the control of muscle development. Proceedings of the Nutrition Society 55, 543-559.
Delhanty P \& Han VKM (1993) The expression of insulin like growth factor (IGF)-binding protein 2 and IGF-II genes in the tissue of the developing ovine fetus. Endocrinology 132, $41-52$.

Derks JB, Giussani DA, Jenkins SL, Wentworth RA, Visser GHA, Padbury JF \& Nathanielsz PW (1997) A comparative study of cardiovascular, endocrine and behavioural effects of betamethasone and dexamethasone administration to fetal sheep. Journal of Physiology 499, 217-226.

Desai M \& Hales CN (1997) Role of fetal and infant growth in programming metabolism in later life. Biological Reviews of the Cambridge Philosophical Society 72, 329-348.

Dickson MC, Saunders JC \& Gilmour RS (1991) The ovine insulin-like growth factor gene: characterisation, expression and identification of a putative promotor. Joumal of Molecular Endocrinology 6, 17-31.

Dodic M, May C, Wintour EM \& Coghlan JR (1997) An early prenatal exposure to maternal dexamethasone leads to hypertensive offspring in sheep. Proceedings of Fetal and Neonatal Physiology Symposium, Cambridge, p. 5. Newmarket, Suffolk: R \& W Publications Ltd.

Forhead AJ, Li J, Gilmour RS \& Fowden AL (1996) Developmental regulation of hepatic insulin-like growth factor-II (IGFII) gene expression in fetal sheep near term: effects of triiodothyronine $\left(\mathrm{T}_{3}\right)$. Journal of Endocrinology 151, Suppl., P34.

Fowden AL (1985) Pancreatic endocrine function and carbohydrate metabolism in the fetus. In Perinatal Endocrinology, pp. 71-90 [E Albrecht and G Pepe, editors]. Ithaca, NY: Perinatology Press.

Fowden AL (1995) Endocrine regulation of fetal growth. Reproduction, Fertility and Development 7, 351-363.

Fowden AL, Apatu RSK \& Silver M (1995) The glucogenic capacity of the fetal pig: developmental regulation by cortisol. Experimental Physiology 80, 457-467.

Fowden AL, Mijovic J \& Silver M (1993) The effects of cortisol on hepatic and renal gluconeogenic enzyme activities in the sheep fetus during late gestation. Journal of Endocrinology 137, 213-222.

Fowden AL, Mundy L, Ousey JC, McGladdery A \& Silver M (1991) Tissue glycogen and glucose-6-phosphatase-activity in the fetal and newborn foals. Journal of Reproduction and Fertility 44, Suppl., 537-542.

Fowden AL \& Silver M (1995) Comparative development of the pituitary-adrenal axis in the fetal foal and lamb. Reproduction in Domestic Animals 30, 170-177.

Fowden AL, Szemere J, Hughes P, Gilmour RS \& Forhead AJ (1996) The effects of cortisol on the growth rate of the sheep fetus during late gestation. Journal of Endocrinology 151, 97105.

Gluckman PD (1995) Insulin like growth factors and their binding proteins. In Fetus and Neonate: Physiology and Clinical Applications, vol. 3, Growth, pp. 97-115 [MA Hanson, JAD Spencer and CH Rodeck, editors]. Cambridge: Cambridge University Press.

Goland RS, Jozak S, Warren WB, Conwell IM, Stark RT \& Tropper PJ (1993) Elevated levels of umbilical cord plasma corticotrophin-releasing hormone in growth retarded fetuses. Journal of Clinical Endocrinology and Metabolism 77, 1174 1179.

Guillery EN, Karniski LP, Mathew MS, Page WV, Orlowski J, Jose PA \& Robillard JE (1995) Role of glucocorticoids in the maturation of renal cortical $\mathrm{Na}^{+} / \mathrm{H}^{+}$exchanger activity during fetal life in sheep. American Journal of Physiology 268, F710F717.

Ingbar DH, Duvick S, Savick SK, Schellhase DE, Detterding R, Jamieson JD \& Shannon JM (1997) Developmental change of fetal rat lung $\mathrm{Na}^{+}-\mathrm{K}^{+}$-ATPase after maternal treatment with 
dexamethasone. American Journal of Physiology 271, L665L672.

Jeffray TM, Berdusco ETM, Wallace M, Fowden A \& Challis JRG (1995) Effects of incremental cortisol and adrenalectomy on plasma corticosteroid binding capacity in fetal sheep. Canadian Journal of Physiology and Pharmacology 73, $1568-1573$

Jones CT \& Rolph TP (1985) Metabolism during fetal life: a functional assessment of metabolic development. Physiological Reviews 65, 357-430.

Kitterman JA, Liggins GC, Campos GA, Clements TA, Forster C, Lee CH \& Creasy RK (1981) Prepartum maturation of the lung in fetal sheep: relation to cortisol. Journal of Applied Physiology 51, 384-390.

Klepac R (1985) Effect of dexamethasone on glycogen deposition in pregnant rats and their fetuses. Experimental Clinical Endocrinology 86, 305-309.

Levitt NS, Lindsay RS, Holmes MC \& Seckl JR (1996) Dexamethasone in the last week of pregnancy attenuates hippocampal glucocorticoid receptor gene expression and elevates blood pressure in the adult offspring in the rat. Neuroendocrinology 64, 412-418.

Li J (1994) Regulation of insulin-like growth factor II gene expression in the late gestation fetal sheep. $\mathrm{PhD}$ Thesis, University of Cambridge.

Li J, Forhead AJ, Gilmour RS \& Fowden AL (1997) The effects of cortisol on growth hormone receptor (GHR) and insulin-like growth factor-I (IGF-I) gene expression in ovine skeletal muscle during late gestation. Proceedings of the 79th Annual Meeting of the Endocrine Society, p. 162. Bethesda, MD: The Endocrine Society Press.

Li J, Owens JA, Owen PC, Saunders JC, Fowden AL \& Gilmour RS (1996a) The ontogeny of hepatic growth hormone (GH) receptor and insulin-like growth factor (IGF-I) gene expression in the sheep fetus during late gestation: developmental regulation by cortisol. Endocrinology 137, 1650-1657.

Li J, Saunders JC, Gilmour RS \& Fowden AL (1996b). Cortisol switches on expression of the liver-specific leader exon of the growth hormone receptor (GHR) gene in ovine fetal liver near term. Journal of Endocrinology 151, Suppl., P33.

Li J, Saunders JC, Gilmour RS, Silver M \& Fowden AL (1993) Insulin-like growth factor-II messenger ribonucleic acid expression in fetal tissues of the sheep during late gestation: effects of cortisol. Endocrinology 132, 2083-2089.

Liggins GC (1994) The role of cortisol in preparing the fetus for birth. Reproduction, Fertility and Development 6, 141-150.

Lim GB, Dodic M, Earnest L, Jeyaseelan K \& Wintour EM (1996) Regulation of ethrythropoietin gene expression in fetal sheep by glucocorticoids. Endocrinology 137, 1658-1663.

Lindsay RS, Lindsay RM, Edwards CRW \& Seckl JR (1996a) Inhibition of $11 \beta$ hydroxysteroid dehydrogenase in pregnant rats and the programming of blood pressure in the offspring. Hypertension 27, 1200-1204.

Lindsay RS, Lindsay RM, Wadell B \& Seckl JR (1996b) Programming of glucose tolerance in the rat: role of placental $11 \beta$-hydroxysteroid dehydrogenase. Diabetologia 39, 1299-1305.

Lü F, Hans VKM, Milne WK, Fraser M, Carter AM, Berdusco ETM \& Challis JRG (1994) Regulation of insulin like growth factor-II gene expression in the ovine fetal adrenal gland by adrenocorticotrophic hormone and cortisol. Endocrinology 134, 2628-2635.

Lumbers ER (1995) Development of renal function in the fetus: a review. Reproduction, Fertility and Development 7, 415-426.

Matthew SG, Yang K \& Challis JRG (1995) Change in glucocorticoid receptor messenger-RNA in the developing ovine pituitary and the effects of exogenous cortisol. Journal of Endocrinology 144, 483-490.
Milley JR (1996) Fetal substrate uptake during increased ovine fetal cortisol concentrations. American Journal of Physiology 271, E186-E191.

Moog F (1979) Endocrine influences on the functional differentiation of the small intestine. Journal of Animal Science 49, 239-249.

NIH Consensus Development Conference (1995) Effect of corticosteroid for fetal maturation on perinatal outcomes. American Journal of Obstetrics and Gynecology 173, Suppl., 253-344.

Olson AL, Robillard JE, Kisker CT, Smith BA \& Perlman S (1991) Negative regulation of angiotensinogen gene expression by glucocorticoids in fetal sheep liver. Pediatric Research 30, 256-260.

Phillips DIW, Barker DJP, Fall CHD, Whorwood CB, Walker BP \& Wood PJ (1997) Low birthweight and raised plasma cortisol concentrations in adult life. Journal of Endocrinology 152 , Suppl., P2.

Phillips ID, Anthony RV, Butler TG, Ross JT \& McMillen IC (1997) Hepatic prolactin receptor gene expression increase in the sheep fetus before birth and after cortisol infusion. Endocrinology 138, 1351-1354.

Pierce RA, Mariencheck WI, Sandefur S, Crouch ED \& Parks WC (1995) Glucocorticoid upregulation of tropoelastin expression during late stages of fetal lung development. American Joumal of Physiology 268, L491-L500.

Price WA, Stiles AD, Moats-Staats BM \& D'Ercole AJ (1992) Gene expression of insulin-like growth factor (IGFs) and Type I IGF receptor and IGF-binding proteins in dexamethasone-induced fetal growth retardation. Endocrinology 130, 1424-1432.

Reinisch JM, Simon NG \& Karwo WG (1978) Prenatal exposure to prednisone in humans and animals retards intra-uterine growth. Science 202, 436-438.

Roberts CT (1997) Post transcriptional regulation of IGF-I biosynthesis. Journal of Endocrinology 152, Suppl., S9.

Sangild PT, Hilsted L, Nexo E, Fowden AL \& Silver M (1994a) Secretion of acid, gastrin and cobalamin-binding proteins by the fetal pig stomach: developmental regulation by cortisol. Experimental Physiology 79, 135-146.

Sangild PT, Silver M, Fowden AL, Turvey A \& Foltman B (1994b) Adrenocortical stimulation of stomach development in the prenatal pig. Biology of the Neonate 65, 378-389.

Sangild PT, Sjostrom H, Noren O, Fowden AL \& Silver $M$ (1995a) The prenatal development and glucocorticoid control of brush-border hydrolases in the pig small intestine. Pediatric Research 37, 207-212.

Sangild PT, Westrom BR, Fowden AL \& Silver M (1994c) Developmental regulation of the porcine exocrine pancreas by glucocorticoids. Journal of Pediatric Gastroenterology and Nutrition 19, 204-212.

Sangild PT, Westrom BR, Silver M \& Fowden AL (1995b) Maturational effects of cortisol on the exocrine abomasum and pancreas in fetal sheep. Reproduction, Fertility and Development 7, 655-658.

Schellenberg JC, Liggins GC, Kitterman JA \& Lee CH (1987) Elastin and collagen in the fetal sheep lung II: Relationship to mechanical properties of the lung. Pediatric Research 22, 339343.

Seckl JR (1994) Glucocorticoids and small babies. Quarterly Journal of Medicine 87, 259-262.

Seckl JR (1997a) Glucocorticoids, feto-placental $11 \beta$-hydroxysteroid dehydrogenase type 2 and the early life origins of adult disease. Steroids 62, 89-94.

Seckl JR (1997b) How safe is long term prenatal glucocorticoid treatment? Journal of the American Medical Association 277, 1077-1079. 
Segar JL, Bedell K, Page WV, Mazursky JE, Nuyt A-M \& Robillard JE (1995) Effect of cortisol on gene expression of the renin-angiotensin system in fetal sheep. Pediatric Research 37, 741-746.

Shelley HJ (1961) Glycogen reserves and their changes at birth and in anoxia. British Medical Bulletin 17, 137-143.

Silver M (1990) Prenatal maturation, the timing of birth and how it is regulated in domestic animals. Experimental Physiology 75, 285-307.

Silver M \& Fowden AL (1988) Induction of labour in domestic animals: endocrine changes and neonatal viability. In The Endocrine Control of the Fetus, pp. 401-411 [W Künzel and A Jensen, editors]. Berlin: Springer-Verlag.

Slotkin TA, Seidler FJ, Kavlock RJ \& Gray JA (1992) Fetal dexamethasone exposure accelerates development of renal function: relationship to dose, cell differentiation and growth inhibition. Journal of Developmental Physiology 17, 55-61.

Stonestreet BS, Hansen NB, Laptook AR \& On W (1983) Glucocorticoid accelerates renal functional maturation in fetal lambs. Early Human Development 8, 331-341.

Tangalakis K, Lumbers ER, Moritz KM, Towstoless MK \& Wintour EM (1992) Effect of cortisol on blood pressure and vascular reactivity in the ovine fetus. Experimental Physiology 77, 709-717.

Townsend SF, Rudolph CD \& Rudolph AM (1991) Cortisol induces perinatal hepatic glucoconeogenesis in the lamb. Journal of Developmental Physiology 16, 71-79.

Towstoless MK, McDougall JG \& Wintour EM (1989) Gestational changes in renal responsiveness to cortisol in the ovine fetus. Pediatric Research 26, 6-10.

Trahair JF (1993) Is fetal enteral nutrition important for normal gastrointestinal growth? A discussion. Journal of Parenteral and Enteral Nutrition 17, 82-85.

Trahair JF, Perry RA, Silver M \& Robinson PM (1987a) Studies on the maturation of the small intestine of the fetal sheep. I. The effects of bilateral adrenalectomy. Quarterly Journal of Experimental Physiology 72, 61-69.

Trahair JF, Perry RA, Silver M \& Robinson PM (1987b) Studies on the maturation of the small intestine in the fetal sheep II. The effects of exogenous cortisol. Quarterly Journal of Experimental Physiology 72, 71-79.

Trahair JF \& Sangild P (1997) Systemic and luminal influence on the perinatal development of the gut. Equine Veterinary Journal 24, Suppl., 40-50.

Venkatesh VC \& Ballard PC (1991) Glucocorticoids and gene expression. American Journal of Respiratory, Cellular and Molecular Biology 4, 301-303.

Wallace MJ, Hooper SB \& Harding R (1995) Effects of elevated fetal cortisol concentration on the volume, secretion and reabsorption of lung liquid. American Journal of Physiology 269, R881-R887.

Wallace MJ, Hooper SB \& Harding R (1996) Role of the adrenal glands in the maturation of lung liquid secretory mechanisms in fetal sheep. American Journal of Physiology 270, R33R40.

Warburton D, Parton L, Buckley S, Cosico L, Enns G \& Saluna T (1988) Combined effects of corticosteroid, thyroid hormones and $\beta$-agonist on surfactant, pulmonary mechanics and $\beta$ receptor binding in fetal lamb lung. Pediatric Research 24, 166-170.

Wintour EM \& Moritz KM (1997) Comparative aspects of fetal renal development. Equine Veterinary Journal 24, Suppl., 5158 .

Wood CE, Cheung CY \& Brace RA (1987) Fetal heart rate, arterial pressure and blood pressure in response to cortisol infusion. American Journal of Physiology 253, R904 R909.

Wood CE \& Cudd TA (1997) Development of the hypothalamicpituitary-adrenal axis of the equine fetus: a comparative review. Equine Veterinary Journal 24, Suppl., 74-82.

Wood CE, Keil LC \& Rudolph AM (1984) Physiological inhibition of ovine fetal plasma renin activity by cortisol. Endocrinology 115, 1792-1796.

Wu SY, Klein AH, Chopra IJ \& Fisher DA (1978) Alterations in tissue thyroxine $5^{\prime}$-monodeiodinating activity in the perinatal period. Endocrinology 103, 235-239.

Yang K (1992) Regulation of gene expression in the ovine fetus. Journal of Reproduction and Fertility 45, Suppl., 85-92. 